Ambiente \& Água - An Interdisciplinary Journal of Applied Science
ISSN 1980-993X - doi:10.4136/1980-993X
www.ambi-agua.net
E-mail: ambi.agua@gmail.com

\title{
Moringa oleifera seed as a natural coagulant to treat low-turbidity water by in-line filtration
}

\author{
ARTICLES doi:10.4136/ambi-agua.2442
}

Received: 12 Jul. 2019; Accepted: 11 Sep. 2019

\author{
João Vitor Mariano Ribeiro ${ }^{1}$; Priscila Vega Andrade1 ${ }^{1}$; \\ Adriano Gonçalves dos Reis ${ }^{1 *}$ \\ ${ }^{1}$ Instituto de Ciência e Tecnologia (ICT). Departamento de Engenharia Ambiental. \\ Universidade Estadual Paulista "Júlio de Mesquita Filho" (UNESP), Estrada Dr. Altino Bondensan, n500, \\ CEP: 12247-016, São José dos Campos, SP, Brazil. E-mail: jvmarianoribeiro@ gmail.com, \\ priscila.vega@unesp.br \\ *Corresponding author. E-mail: adriano.reis@unesp.br
}

\begin{abstract}
This study evaluated the use of Moringa oleifera (MO) seed as a natural coagulant for the removal of turbidity and apparent color in the water treatment with low initial turbidity through the in-line filtration technique. The morphology and surface charge were investigated by characterization techniques such as optical microscopy, laser particle size, and zeta potential. The cationic proteins of the MO seed were extracted in aqueous solution. The jar test showed the potability standards for turbidity and apparent color were reached in the $\mathrm{pH}$ range from 4.0 to 8.5 and dosages $\geq 5 \mathrm{mg} \mathrm{L}^{-1}$ of $\mathrm{MO}$. The dominant coagulation mechanism is adsorption and charge neutralization. This study showed that treating low-turbidity water with MO seed by the in-line filtration technique is possible.
\end{abstract}

Keywords: adsorption and charge neutralization, coagulation, water treatment.

\section{Semente de Moringa oleifera como coagulante natural para tratar águas de baixa turbidez via filtração direta em linha}

\section{RESUMO}

O objetivo deste estudo é avaliar o uso de semente de Moringa oleifera (MO) como um coagulante natural para remoção de turbidez e cor aparente no tratamento de água de abastecimento com baixa turbidez inicial via técnica de filtração direta em linha. A morfologia e carga de superfície foram investigadas por técnicas de caracterização como microscopia óptica, tamanho de partícula a laser e potencial zeta. As proteínas catiônicas da semente de MO foram extraídas em meio aquoso. Os ensaios de Jar test apontaram que os padrões de potabilidade para turbidez e cor foram atingidos na faixa de $\mathrm{pH}$ de 4,0 a 8,5 e dosagens $\geq 5 \mathrm{mg}$ $\mathrm{L}^{-1}$ de MO. O mecanismo de coagulação dominante é o de adsorção e neutralização de carga. O estudo evidencia que é possível tratar água de baixa turbidez com semente de MO pela técnica de filtração direta em linha.

Palavras-chave: adsorção e neutralização de carga, coagulação, tratamento de água.

This is an Open Access article distributed under the terms of the Creative Commons Attribution License, which permits unrestricted use, distribution, and reproduction in any medium, provided the original work is properly cited. 


\section{INTRODUCTION}

Water treatment usually uses chemical coagulants and, in general, these reagents are aluminum and iron salts, with low cost and high efficiency (Amagloh and Benang, 2009). However, access to treated water or high costs of imported chemicals and low availability of chemical coagulants can be a problem in some developing countries (Paterniani et al., 2009). Studies also suggest the consumption of water treated with aluminum sulphate may pose a risk for Alzheimer's disease, due to the ingestion of chemical residues of aluminum in the water (Rondeau et al., 2000).

Moringa oleifera (MO) is a plant native to the Himalayas, already cultivated all around the globe (Arnoldsson et al., 2008; Kansal and Kumari, 2014). Used for various purposes, its seeds can be used for water clarification and treatment, being an alternative to the conventional coagulants. The performance of the seeds as a coagulant is due to the fact that they are composed of several cationic proteins, which makes their zeta potential positive, allowing the destabilization of particles that cause water turbidity (Baptista et al., 2017). Regarding the toxicity of MO, the analyses performed so far point to a low toxicity of the material and have shown that it is not harmful to human health (Grabow et al., 1985; Kavitha et al., 2012).

Most of the studies found in the literature using seeds of MO for water treatment point to a high efficiency of the coagulant (92 to $99 \%$ ), by coagulation, flocculation and sedimentation, for water with high turbidity: 50 to 200 NTU (Paterniani et al., 2009; Arnoldsson et al., 2008; Kansal et al., 2014; Baptista et al., 2017; Pritchard et al., 2010; Valverde et al., 2018). However, using the MO seeds for the treatment of low-turbidity water $(<40 \mathrm{NTU})$, by the same unit operations reduces efficiency, reaching, on average, only 50\% removal (Arnoldsson et al., 2008; Kansal et al., 2014; Pritchard et al., 2010), which makes it impractical to use MO seed in aqueous extraction as a coagulant for water with low turbidity for water treatment. In this context, an investigation of the use of MO seed in an alternative water treatment technique by in-line filtration, evaluating the type of floc formed and potential zeta and its correlation with the dominant coagulation mechanism, is of interest and is discussed in this article.

\section{MATERIALS AND METHODS}

Figure 1 shows a diagram of the main steps developed in this study.

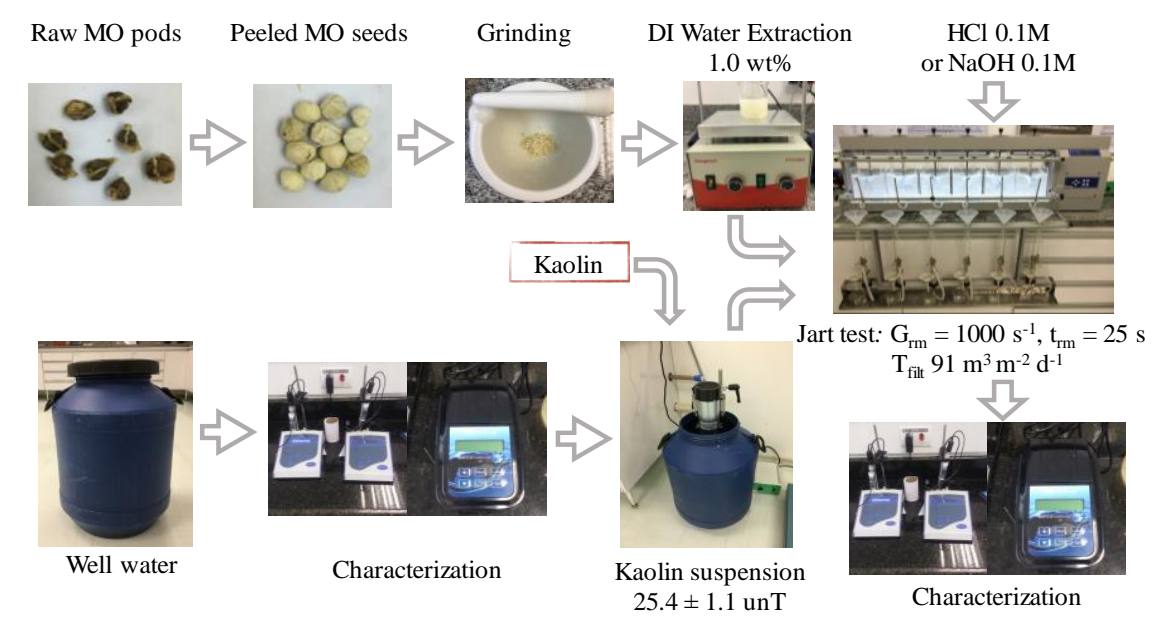

Figure 1. Diagram of the main steps developed in this study.

\subsection{Materials}

Prior to any treatment, the raw water was drawn from the well of the Technological Park of São José dos Campos, SP, Brazil (2309'26.4" S, 4547'39.2" W). Kaolin was used as a 
model suspension to simulate low-turbidity water. Suspensions for the experiments were prepared by diluting the stock suspension of kaolin $\left(58 \mathrm{~g} \mathrm{~L}^{-1}\right)$ to standardize water turbidity at $25 \pm 2$ NTU. The MO seeds used in this study were acquired in Birigui, SP, Brazil $\left(21^{\circ} 15^{\prime} 11.9^{\prime \prime} \mathrm{S}, 50^{\circ} 19^{\prime} 49.0^{\prime \prime} \mathrm{W}\right)$. For the aqueous extraction of the proteins present in the MO seeds, a sufficient number of seeds was peeled and grinded, and deionized water was added to obtain $1.0 \mathrm{wt} \%$. The grinding was done manually with mortar and pestle. The solution was stirred and then sedimented for 15 minutes in each step, with only the supernatant being used as a coagulant. No additional purification steps were performed, varying dosages from 1 to 30 $\mathrm{mg} \mathrm{L} \mathrm{L}^{-1}$ of crude aqueous coagulant of MO. The solutions were used on the same day of preparation and were not stored for later use to avoid the effects of storage on coagulation efficiency as reported in the literature (Katayon et al., 2006). For the $\mathrm{pH}$ variation $\mathrm{HCl} 0.1 \mathrm{M}$ or $\mathrm{NaOH} 0.1 \mathrm{M}$ was used.

\subsection{Characterization techniques}

The water was characterized by $\mathrm{pH}$, alkalinity, acidity and temperature in a Tecnofon $\mathrm{mPA}$ $210 \mathrm{pH}$ meter. Its turbidity was measured by the Policontrol AP2000 nephelometer, its apparent color by the Policontrol AquaColor colorimeter, and the conductivity by the Tecnofon mCA150 Conductivity Meter. The particle size was analyzed in a Cilas 1190 Particle Size Analyzer. The zeta potential was analyzed by Beckman Coulter's Delsa Nano C Particle Analyzer. The floc morphology was evaluated by the Leica $205 \mathrm{C}$ stereo microscope.

\subsection{In-line filtration experiments}

For the treatment of low-turbidity kaolin suspension via in-line filtration, tests were carried out with a jar test from PoliControl - FlocControl III Model, with 6 jars and sand filter coupled with effective sand size of $0.59 \mathrm{~mm}$ (FLA2). The filtration rate was $91 \mathrm{~m}^{3} \mathrm{~m}^{-2} \mathrm{~d}^{-1}$, and the final sample was collected after $20 \mathrm{~min}$ of filtration run. The mean velocity gradient of rapid-mix $\left(\mathrm{G}_{\mathrm{rm}}\right)$ used was $1000 \mathrm{~s}^{-1}$ with time $\left(\mathrm{t}_{\mathrm{rm}}\right)$ of $25 \mathrm{~s}$. To determine the need for the flocculation step, $30 \mathrm{mg} \mathrm{L}^{-1}$ of $\mathrm{MO}$ was used, without $\mathrm{pH}$ adjustment, with a velocity gradient of $50 \mathrm{~s}^{-1}$ and times of $0,5,10,15,20$, and $25 \mathrm{~min}$. For turbidity and apparent color coagulation diagrams, the parameters turbidity, apparent color, and $\mathrm{pH}$ were analyzed, comprising dosages from 0 to 30 $\mathrm{mg} \mathrm{L}^{-1}$ and $\mathrm{pH}$ between 4.0 and 9.5 .

\section{RESULTS AND DISCUSSIONS}

\subsection{Characterization}

Table 1 shows the characteristics of the well water used in this study.

Table 1. Characterization of the well water used in this study.

\begin{tabular}{lcccc}
\hline Quality parameter (unity) & Average & Standard deviation & Min. value & Max. value \\
\hline $\mathrm{pH}$ & 6.70 & 0.17 & 6.35 & 7.10 \\
Temperature $\left({ }^{\circ} \mathrm{C}\right)$ & 23.9 & 0.9 & 22.1 & 25.0 \\
Conductivity $\left(\mu \mathrm{S} \mathrm{cm}^{-1}\right)$ & 54.5 & 4.9 & 44.5 & 68.3 \\
Turbidity $(\mathrm{NTU})$ & 0.14 & 0.09 & 0.10 & 0.39 \\
Apparent color $(\mathrm{CU})$ & 2.2 & 1.0 & 0.6 & 3.9 \\
Total alkalinity $\left(\mathrm{mg} \mathrm{CaCO}_{3} \mathrm{~L}^{-1}\right)$ & 26.9 & 2.1 & 23.0 & 30.5 \\
Total acidity $\left(\mathrm{mg} \mathrm{CaCO}_{3} \mathrm{~L}^{-1}\right)$ & 15.3 & 2.5 & 11.0 & 21.5 \\
\hline
\end{tabular}

The water of the study shows slightly acidic character, low alkalinity, acidity, turbidity, and apparent color, which was expected due to the origin of the water. The low-conductivity value indicates low presence of dissolved ions. After kaolin addition, the turbidity and apparent 
color of the suspension were increased to $25.4 \pm 1.1 \mathrm{NTU}$ and 53.4 $\pm 3.8 \mathrm{CU}$, respectively. This low-turbidity kaolin suspension was used in the jar tests.

The granulometric distribution of the kaolin suspension has a normal distribution appearance, with an average diameter of $11.65 \mu \mathrm{m}$, but it has particles as small as $0.04 \mu \mathrm{m}$ and as large as $56.00 \mu \mathrm{m}$. The kaolin suspension had an average zeta potential of $-32.9 \pm 0.6 \mathrm{mV}$, corresponding to an average electrophoretic mobility of $-2.5608 \pm 0.0434 \mu \mathrm{m} . \mathrm{cm} . \mathrm{V}^{-1} . \mathrm{s}^{-1}$. Therefore, the particles are in stabilized colloidal state due to the predominant micrometer particle size and the negative zeta potential.

\subsection{Use of MO seed for water treatment by in-line filtration}

\subsubsection{Assessment of the need for flocculation}

Direct filtration is comprised of coagulation followed by flocculation and filtration. In-line filtration is comprised of coagulation followed by filtration (Di Bernardo et al., 2002). Figure 2 shows the effect in particle size and remaining turbidity as a function of different flocculation times.

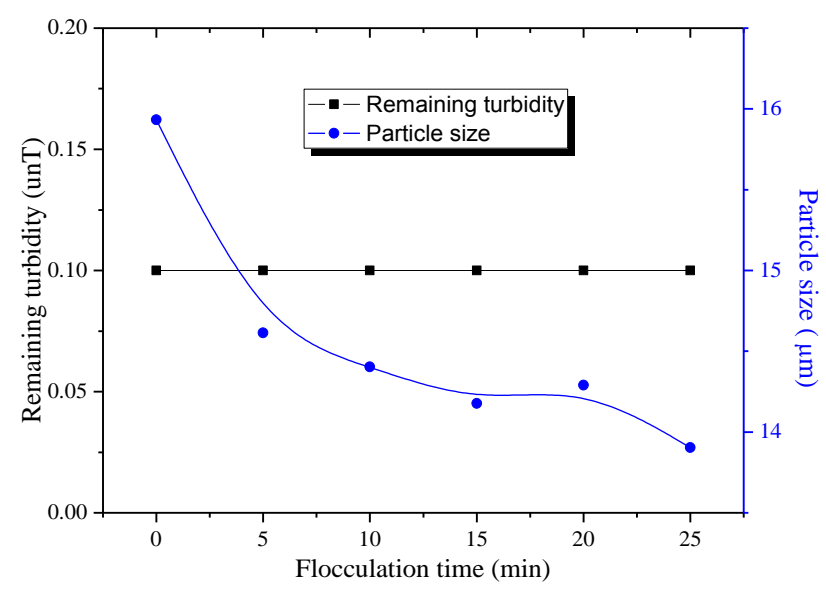

Figure 2. Results of remaining turbidity and particle size as a function of different flocculation times.

From the results shown in Figure 2, the remaining turbidity was independent of the flocculation time. Therefore, flocculation is not necessary to guarantee the quality of the treated water for the conditions studied. In relation to the particle size, the granulometric distribution showed that the mean diameter of $11.65 \mu \mathrm{m}$ of the particles in the kaolin suspension increased to $15.9 \mu \mathrm{m}$ for the coagulated and non-flocculated particles; that is, an increase of about $37 \%$ in particle size. This increase is related to the destabilization of the colloidal particles, which allows them to agglomerate and to form microflocs. Differently, the larger the flocculation time was, the lower the particle size. Although this result did not directly influence the turbidity removal efficiency after the sand filter, since the particles were already destabilized, it shows that, in this case, flocculation does not improve the turbidity removal process using MO in direct filtration. Whether or not to include the flocculation step for direct filtration requires practical studies with the water of the study. According to Di Bernardo et al. (2002), if particles with a medium size in the range of 1 to $3 \mu \mathrm{m}$ predominate, promoting flocculation after coagulation is advisable, to reduce ETA's operational costs and to enable the production of better quality water. Contrarily, when the size of coagulated particles is adequate to ensure the satisfactory performance of the filters, flocculation should be dispensed with. Otherwise, the costs of ETA implantation, operation and maintenance would be increased unnecessarily. Consequently, for the construction of the coagulation diagrams, the $G_{\mathrm{rm}}$ conditions of $1000 \mathrm{~s}^{-1}$ and $t_{\mathrm{rm}}$ of $25 \mathrm{~s}$ and without flocculation were used, that is, in-line filtration. 


\subsubsection{Coagulation diagrams for in-line filtration and determination of the dominant coagulation mechanism}

Figure 3 shows the coagulation diagrams of remaining turbidity and apparent color, and the profile for both diagrams is very similar.
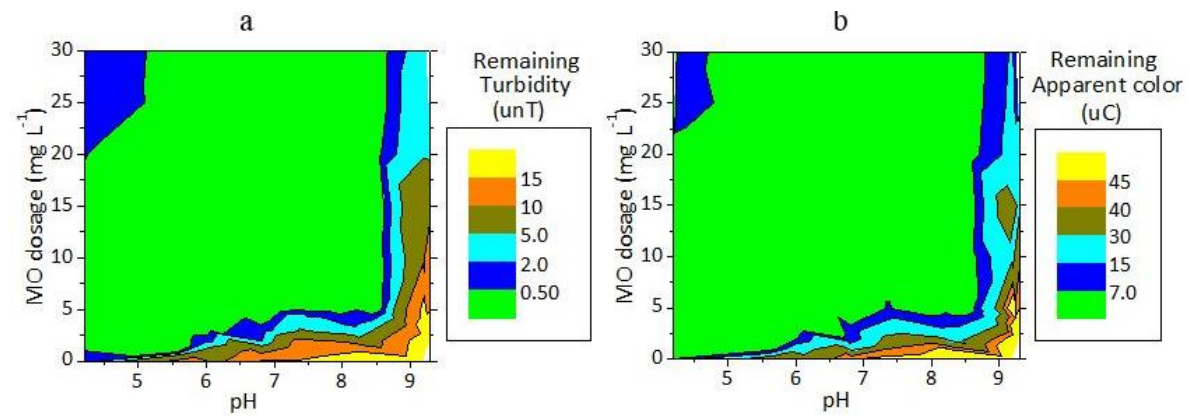

Figure 3. In-line filtration coagulation diagram as a function of the dosage of $\mathrm{MO}\left(\mathrm{mg} \mathrm{L}^{-1}\right) \mathrm{x}$ coagulation $\mathrm{pH}$ for a) remaining turbidity (NTU) and b) remaining apparent color $(\mathrm{CU})$.

According to Figure 3 and considering the parameters of potability after in-line filtration, both turbidity $(\leq 0.5 \mathrm{NTU})$ and apparent color $(\leq 15 \mathrm{CU})$ are met in the green area at dosages above $1 \mathrm{mg} \mathrm{L}^{-1}$ of $\mathrm{MO}$ for $\mathrm{pH}$ between 4 and 8.5 and at dosages above $5 \mathrm{mg} \mathrm{L}^{-1}$ for $\mathrm{pH}$ between 6 and 8.5, which is the most usual pH range for potable water (Brasil, 2017; WHO, 2017). Figure 3 also allows us to observe that the higher the $\mathrm{pH}$, the greater the coagulant consumption to reach low turbidity. At $\mathrm{pHs}$ greater than 8.5, a reduction in turbidity and color removal efficiency is noted. It is related to the Isoelectric Point of the MO values, that are from 8 to 10 according to the literature (Kansal et al., 2014; Pritchard et al., 2010; Ndabigengesere et al., 1995). Also, the lower the $\mathrm{pH}$, the lower the coagulant consumption to reach low turbidity. On the other hand, the combination of low-pH and high-MO dosage leads to worsening turbidity removal, according to the blue area in the upper left corner of Figure 3. This behavior is probably related to particle restabilization.

To evaluate the particle restabilization, the remaining turbidity and flocs zeta potential as a function of the dosage of MO required is shown in Figure 4.

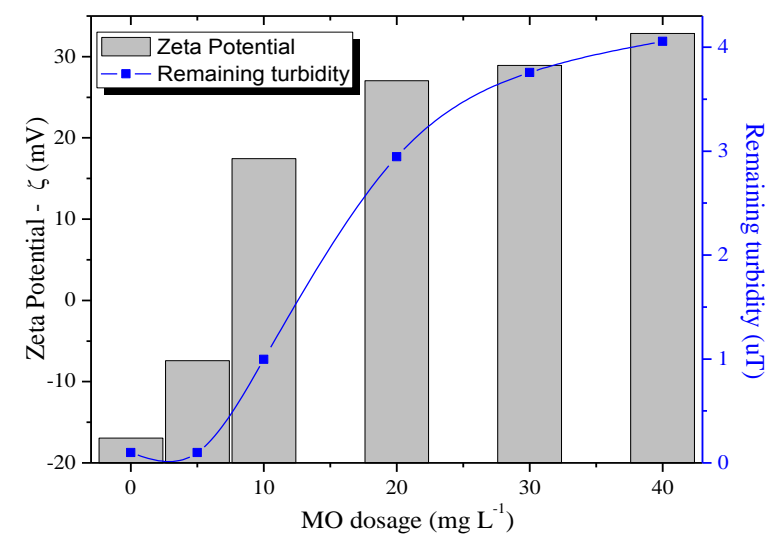

Figure 4. Remaining turbidity (NTU) and zeta potential $(\mathrm{mV})$ as a function of the $\mathrm{MO}\left(\mathrm{mg} \mathrm{L}^{-1}\right)$ for the $\mathrm{pH}$ of 3.8 .

For kaolin suspension at $\mathrm{pH} 3.8$, even without the addition of $\mathrm{MO}\left(0 \mathrm{mg} \mathrm{L}^{-1}\right)$, the remaining turbidity is 0.1 NTU. The reason for this high turbidity removal efficiency in kaolin suspension after filtration at $\mathrm{pH} 3.8$, even without the addition of coagulant, is that this $\mathrm{pH}$ is very close to the point of zero charge (PZC) of kaolin. Bakatula et al. (2018) reported a PZC value for kaolin 
between $3.01 \pm 0.03$ and $3.25 \pm 0.12$. Moayedi et al. (2011) reported an isoelectric point value of 3.1 for kaolin. According to Figure 4, the zeta potential found for kaolin suspension at $\mathrm{pH}$ 3.8 without addition of MO was $-17.0 \mathrm{mV}$. The suspended particles will be stable the further away from zero their zeta potential values, whether positive or negative. Thus, for a zeta potential of $-17 \mathrm{mV}$ there is a greater tendency to aggregate and floc formation because the zeta potential is not as far from zero. After addition of $5 \mathrm{mg} \mathrm{L}^{-1}$ of $\mathrm{MO}$, the zeta potential rose to $7.4 \mathrm{mV}$, and the remaining turbidity remained at $0.1 \mathrm{NTU}$, showing that in the charge equilibrium between negative kaolin surface charge and positive MO protein charge, flocs tend to zero charge. However, from the dosage of $10 \mathrm{mg} \mathrm{L}^{-1}$, the zeta potential became positive and gradually increased with increasing dosage. At the same time, with the increase in the positive charge of the flocs of kaolin/MO protein surface, the remaining turbidity was also increasing, worsening the water quality. Once the concentration of MO proteins exceeds the limit required for balancing the negative kaolin charges, the resulting suspension has an excess of positive proteins, which generates the increasingly positive zeta potential, causing the restabilization of the colloidal particles. The phenomenon of restabilization in high doses of MO supports the hypothesis of a dominant mechanism of coagulation through the adsorption and neutralization of charges.

The isoelectric point of the microflocs with addition of MO solution was determined for the pHs of 6.8 and 3.8, according to Figure 5.
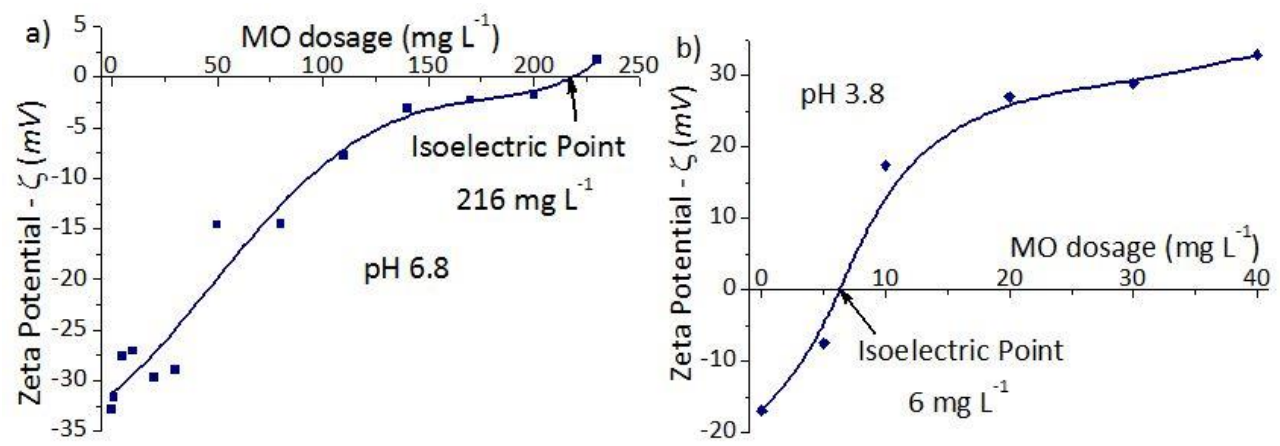

Figure 5. Variation of the zeta potential of the microflocs as a function of the MO to dosage for a) $\mathrm{pH}$ of 6.8 and, b) $\mathrm{pH}$ of 3.8.

Figure 5 shows that increasing MO dosage consequently increases zeta potential. In relation to the $\mathrm{pH}$ of 6.8 , the isoelectric point was reached with $216 \mathrm{mg} \mathrm{L}^{-1}$ of $\mathrm{MO}$, and for $\mathrm{pH}$ of $3.8,6 \mathrm{mg} \mathrm{L}^{-1}$ was necessary to reach the isoelectric point. The MO-based coagulant extracted by aqueous solution has the capacity, therefore, to act directly on the zeta potential of the kaolin suspension to the point of totally neutralizing the charge of the particles. This capacity is typical of coagulation by adsorption and neutralization of charges. However, the dosage required of $216 \mathrm{mg} \mathrm{L}^{-1}$ of MO to reach the isoelectric point of kaolin suspension is much higher than that required to achieve 0.1 turbidity remaining after in-line filtration, which, through the coagulation diagram (Fig. 3a), was $4 \mathrm{mg} \mathrm{L}^{-1}$ for the $\mathrm{pH}$ of 6.8. At this dosage, zeta potential of the flocs reduced to about $-28 \mathrm{mV}$ (Fig. 5a). For a solution of kaolin without addition of $\mathrm{MO}$ at $\mathrm{pH} 3.8$, the zeta potential found was $-17.0 \mathrm{mV}$ (Fig. 5b), and the remaining turbidity after filtration for this case was $0.1 \mathrm{NTU}$; that is, the particles were already destabilized. The optimal zeta potential for destabilization of the particle does not need to be necessarily zero in the adsorption and charge neutralization mechanism. The van de Waals attractive forces among the resulting microflocs only need to predominate over the repulsive forces, allowing them to aggregate. There is no single zeta potential value in which particle aggregation will ever occur. For each water studied and each coagulant, a single zeta potential value possibly can be observed where the particles can aggregate, and this value must be determined experimentally. 

pH 6.6.

Figure 6 shows the morphology of the particles before and after coagulation with MO at
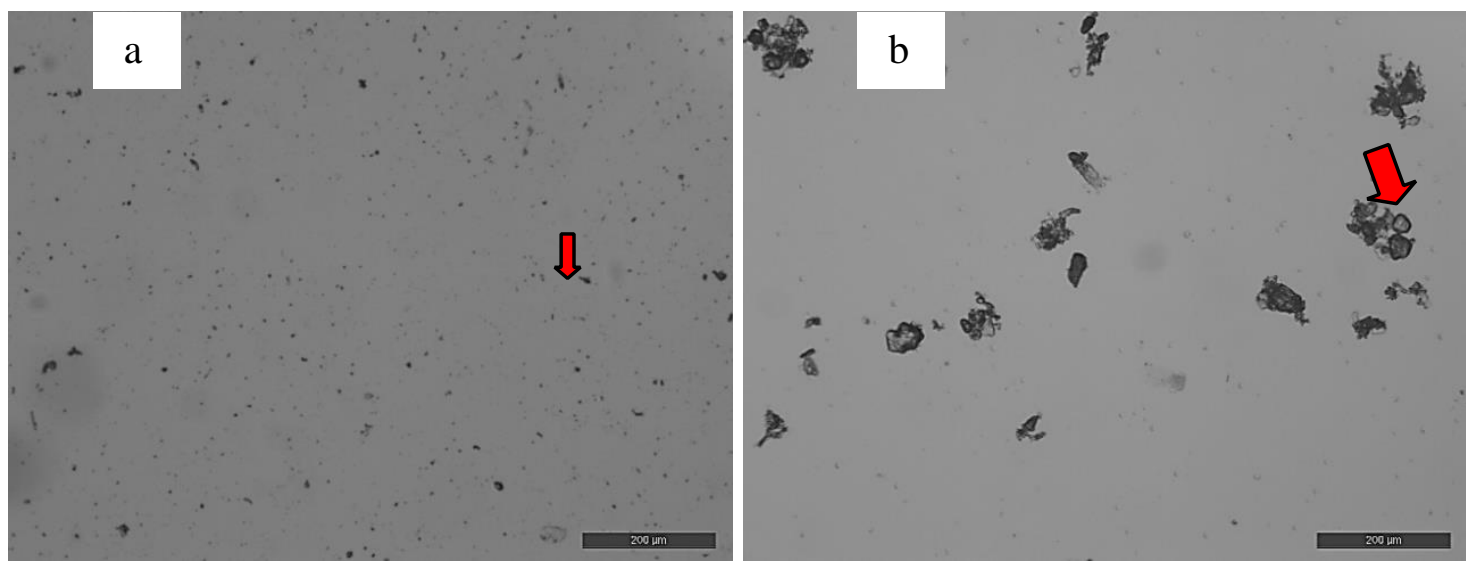

Figure 6. Morphology of the a) kaolin suspension particles before coagulation and (b) microflocs after coagulation with $10 \mathrm{mg} \mathrm{L}^{-1}$ of MO.

Figure 6a shows before coagulation the kaolin particles are dispersed in the solution (arrow indication), as expected for a colloidal solution due to electrostatic repulsion. Figure $6 \mathrm{~b}$ shows the presence of microflocs formed by the agglomeration of kaolin particles (arrow indication), which are now destabilized by cationic proteins of MO. This type of microfloc formed is typical of the mechanism of adsorption and neutralization of charge, different from the sweep mechanism, in which an amorphous precipitate of metal hydroxide involves and incorporates kaolin.

Thus, considering the ability of the solution by aqueous extraction of the MO seed to neutralize the negative zeta potential of colloids present in the kaolin suspension, and to restabilize the particles when MO is added in excess, forming microflocs by aggregation of kaolin particles destabilized, it can be inferred that the dominant mechanism of coagulation using MO is the adsorption and neutralization of charges.

\section{CONCLUSIONS}

Considering the study of MO seed as a natural coagulant to treat low-turbidity water by inline filtration, the following conclusions can be drawn:

- Low-turbidity water can be treated by in-line filtration using MO seed as coagulant with high efficiency (98\%) of turbidity and apparent color removal.

- Flocculation didn't improve the water quality due to particle size, and the treatment can be performed by in-line filtration.

- The dominant coagulation mechanism is adsorption and charge neutralization.

This study, therefore, concludes that using MO seed to treat low-turbidity water by in-line filtration using a low dosage of the coagulant is possible, and it can be an attractive alternative to water treatment for populations that do not have access to drinking water.

\section{ACKNOWLEDGEMENTS}

The authors are grateful to $\mathrm{CNPq}$ (grants Universal 403070/2016-3 and PIBIC 159397/2017-0) for the financial support. 


\section{REFERENCES}

AMAGLOH, F. K.; BENANG, A. Effectiveness of Moringa Oleifera Seed as Coagulant for Water Purification. African Journal of Agricultural Research, v. 4, n. 2, p. 119-123, 2009.

ARNOLDSSON, E.; BERGMAN, M.; MATSINHE, N.; PERSSON, K. M. Assessment of drinking water treatment using Moringa oleifera natural coagulant. Vatten, v. 64, p. 137150, 2008.

BAKATULA, E. N.; RICHARD, D. NECULITA, C. M.; ZAGURY, G. J. Determination of point of zero charge of natural organic materials. Environmental Science and Pollution Research, v. 25, p. 7823-7833, 2018. https://doi.org/10.1007/s11356-017-1115-7

BAPTISTA, A. T. A.; SILVA, M. O.; GOMES, R. G.; BERGAMASCO, R. VIEIRA, M. F.; VIEIRA, A. M. S. Protein fractionation of seeds of Moringa oleifera lam and its application in superficial water treatment. Separation and Purification Technology, v. 180, p. 114-124, 2017. https://doi.org/10.1016/j.seppur.2017.02.040

BRASIL. Ministério da Saúde. Portaria de Consolidação n ${ }^{0}$ 5, de 28 de setembro de 2017. Consolidação das normas sobre as ações e os serviços de saúde do Sistema Único de Saúde. Anexo XX: do controle e da vigilância da qualidade da água para consumo humano e seu padrão de potabilidade. Diário Oficial [da] União: seção 1, Brasília, DF, 3 out. 2017.

DI BERNARDO, L.; DANTAS, A. de B.; VOLTAN, P. E. N. Ensaios de tratabilidade de água e dos resíduos gerados em estações de tratamento de água. São Carlos: RiMa, 2002.

GRABOW, W. O. K.; SLABBERT, J. L.; MORGAN, W. S. G.; JAHN, S. Toxicity and mutagenicity evaluation of water coagulated with Moringa oleifera seed preparations using fish, protozoan, bacterial, coliphage, enzyme and Ames Salmonella assays. Water SA, v. 11, n.1, p. 9-14, 1985.

KANSAL, S. K.; KUMARI, A. Potential of M. oleifera for the treatment of water and wastewater. Chemical Reviews, v. 114, n. 1, p. 4993-5010, 2014. https://doi.org/10.1021/cr400093w

KATAYON, S.; NOOR, M. J. M. M.; ASMA, M.; GHANI, L. A. A.; THAMER, A. M.; AZNI, I.; AHMAD, J.; KHOR, B. C.; SULEYMAN, A. M. Effects of storage conditions of Moringa oleifera seeds on its performance in coagulation. Bioresource Technology, v. 97, n. 13, p. 1455-1460, 2006. https://doi.org/10.1016/j.biortech.2005.07.031

KAVITHA, C.; RAMESH, M.; SATYANARAYANAN, S. K.; LAKSHMI, S. A. Toxicity of Moringa oleifera seed extract on some hematological and biochemical profiles in a freshwater fish, Cyprinus carpio. Experimental and Toxicologic Pathology, v. 64, n. 78, p. 681-687, 2012. https://doi.org/10.1016/j.etp.2011.01.001

MOAYEDI, H.; HUAT, B. B. K.; KAZEMIAN, S.; DANESHMAND, S.; MOAZAMI, D.; NIROUMAND, H. Electrophoresis of Suspended Kaolinite in Multivalent Electrolyte Solution. International Journal of Electrochemical Science, v. 6, p. 6514-6524, 2011.

NDABIGENGESERE, A.; NARASIAH, K. S.; TALBOT, B. G. Active agents and mechanism of coagulation of turbid waters using Moringa oleifera. Water Research, v. 29, p. 703710, 1995. https://doi.org/10.1016/0043-1354(94)00161-Y 
PATERNIANI, J. E. S.; MANTOVANI, M. C.; ANNA, M. R. S. Uso de sementes de Moringa oleifera para tratamento de águas superficiais. Revista Brasileira de Engenharia Agrícola e Ambiental, v. 13, n. 6, p. 765-771, 2009. https://dx.doi.org/10.1590/S141543662009000600015

PRITCHARD, M.; CRAVEN, T.; MKANDAWIRE, T.; EDMONDSON, A. S.; O’NEILL, J. G. A study of the parameters affecting the effectiveness of Moringa oleifera in drinking water purification. Physics and Chemistry of the Earth, v. 35, n. 13-14, p. 791-797, 2010. https://doi.org/10.1016/j.pce.2010.07.020

RONDEAU, V.; COMMENGES, D.; JACQMIN-GADDA, H.; DARTIGUES, J. F. Relation between aluminum concentrations in drinking water and Alzheimer's disease: an 8-year follow-up study. American journal of epidemiology, v. 152, n. 1, p. 59-66, 2000. https://doi.org/10.1093/aje/152.1.59

VALVERDE, K. C.; PACCOLA, E. A. S.; POMINI, A. M.; YAMAGUCHI, N. U.; BERGAMASCO, R. Combined water treatment with extract of natural Moringa oleifera Lam and synthetic coagulant. Revista Ambiente e Agua, v. 13, n. 3, p. 1-11, 2018. http://dx.doi.org/10.4136/ambi-agua.2135

WHO. Guidelines for drinking-water quality: fourth edition incorporating the first addendum. Geneva, 2017. 